\title{
Association between left ventricular myocardial resting perfusion and intramyocardial fat deposition in patients with chronic myocardial infarction
}

\author{
James W Goldfarb*, Marguerite Roth and Madhavi Kadiyala
}

Address: St Francis Hospital, Roslyn, NY, USA

* Corresponding author

from 13th Annual SCMR Scientific Sessions

Phoenix, AZ, USA. 21-24 January 2010

Published: 21 January 2010

Journal of Cardiovascular Magnetic Resonance 20 I0, I2(SuppI I):PI75 doi:I0.I I86/I532-429X-I2-SI-PI75

This abstract is available from: http://jcmr-online.com/content/I2/SI/PI75

(C) 2010 Goldfarb et al; licensee BioMed Central Ltd.

\section{Introduction}

Ischemic evaluation of the left ventricle (LV) by MR imaging can be performed using a combination of rest and stress images during a bolus contrast injection. Additionally, late-gadolinium-enhanced images are used determine the presence and extent of infarction. Myocardial tissue composition and vascular status may be determinants of myocardial blood flow in the resting and stress states. The effects of fibrosis as well as fat deposition on MR first-pass perfusion images have not been well studied. LV fat deposition is easily detected with MR imaging and is associated with chronic LV myocardial infarction, with a prevalence of approximately 60\%. Assessment of perfusion in myocardial segments with fibrosis is clinically relevant for the determination of peri-infarct ischemia.

\section{Purpose}

To determine the association between myocardial tissue composition and resting perfusion abnormalities detected by MR imaging.

\section{Methods}

Thirty asymptomatic patients with chronic LV myocardial infarction underwent MR imaging at $1.5 \mathrm{~T}$. Myocardial fat deposition was determined with fat sensitive multi-gradient-echo imaging and water-fat separation processing. Images were acquired in long and parallel short axis orientations. First-pass resting perfusion assessment was performed with a bolus injection of $0.05 \mathrm{mmol} / \mathrm{kg}$ gadolinium contrast agent using a spoiled gradient-echo pulse sequence (23 cases with TSENSE-EPI acceleration and 7 cases without). Five to seven slices, depending on resting heart rate, were acquired for each patient in a combination of long and short axis orientations. Blinded visual assessment of the rest perfusion images was performed by an experienced physician. The association of resting perfusion defects with myocardial fat deposition was statistically evaluated using the Kappa test. A p-value was calculated using the method of Fleiss.

\section{Results}

Twenty patients had fat deposition and fourteen patients had resting myocardial defects. The observed agreement was $73 \%$. One patient without fat deposition had a resting perfusion defect. Seven patients with LV fat deposition did not have observed resting perfusion defects. The Kappa statistic value was 0.48 , indicating moderate agreement. The p-value was 0.004 , indicating that the agreement between LV myocardial resting perfusion defects and fat deposition is not by chance, Figure 1.

\section{Conclusion}

In patients with LV chronic myocardial infarction, resting perfusion defects are rare in the absence of fat deposition. Resting perfusion abnormalities are common in the presence of LV fat deposition. Further studies will clarify if lack of perfusion alters the tissue composition or the altered tissue composition results in perfusion defects. 


\begin{tabular}{r|rrr|r} 
& \multicolumn{2}{|c}{ Fat Deposition } & \multicolumn{2}{c}{ Total } \\
\hline Resting Perfusion Defect & Negative & Positive & \multicolumn{1}{c}{ Tot } \\
\hline Negative & 9 & 7 & 16 \\
Positive & 1 & 13 & 14 \\
\hline Total & 10 & 20 & 30
\end{tabular}

\section{Figure I}

Publish with Bio Med Central and every scientist can read your work free of charge

"BioMed Central will be the most significant development for disseminating the results of biomedical research in our lifetime. " Sir Paul Nurse, Cancer Research UK

Your research papers will be:

- available free of charge to the entire biomedical community

- peer reviewed and published immediately upon acceptance

- cited in PubMed and archived on PubMed Central

- yours - you keep the copyright 